\title{
Introduction of Advanced Manufacturing Technology: a literature review
}

\author{
Kennedy D Gunawardana \\ Department of Accounting \\ University of Sri Jayewardenepura, Nugegoda.
}

\begin{abstract}
This paper presents an overview and guidance for manufacturing companies which are preparing to invest in Advanced Manufacturing Technology (AMT). The purpose of this paper is to introduce AMT to Local context and explain the reasons why the company may encounter problems with adopting AMT. In addition to that, the author suggests many avenues to look at AMT applications and the many suggestions offered by the relevant literature for improving the performance of using AMT investment. Further, the research work here aims to assist managers to understand the benefits, types and investment of AMT and identify the problems in the local context. The author of this paper believes that proper understanding of AMT will encourage more firms to invest in AMT and to realize the benefits to make more contributions to society by improving world standard quality of product.
\end{abstract}

\section{Introduction}

The market place of the twenty-first century is evolving into one of merging national markets, fragmented consumer markets, and rapidly changing product technologies. These changes are driving firms to compete, simultaneously, along several different dimensions: design, manufacturing, distribution, communication, sales and others. Although manufacturing has not been utilized as a competitive weapon historically, the market place of the twenty first century will demand that manufacturing assume a crucial role in the new competitive arena.

Progress in human society has been accomplished by the creation of new technologies. The last few years have witnessed unparalleled changes throughout the world. Rapid changes in the markets demand drastically shortened product life cycles and high-quality products at competitive prices. Customers now prefer a large variety of products. This phenomenon has inspired manufacturing firms to look for progressive computerized automation in various processes. Thus mass production is being replaced by low-volume, high-variety production. Manufacturing firms have recognized the importance of flexibility in the manufacturing system to meet the challenges posed by the pluralistic market. The concept of flexibility in manufacturing systems has attained significant importance in meeting the challenges for a variety of products of shorter leadtimes, together with higher productivity and quality. The flexibility is the underlying concept behind the transition from traditional methods of production to the more automated and integrated methods. They stress that firms implementing automation projects should prioritize their needs for different flexibilities for long-range strategic perspectives.

Intensifying global competition and rapid advancement of manufacturing technology are two realties in today's business environment. These have combined to shift the business strategic priorities toward quality, cost effectiveness and responsiveness to marketplace changes.

(c) 2006 Sabaragamuwa University Journal, vol 6, no.1, pp 116-134 116 
The quest for lower operating costs and improved manufacturing efficiency has forced a large number of manufacturing firms to embark on AMTs projects of various types. Dramatic developments in AMT at various organizational levels can be attributed to numerous benefits that improve the competitive position of the adopting companies. AMT impact not just manufacturing, but the whole business operations, giving new challenges to a firm's ability to mange both manufacturing and information technologies.

AMT can also provide distinctive competitive advantages in cost and process leadership. Events of the last decade, such as the US productivity problems, Japanese manufacturing success stories and the competitive global economy, have moved manufacturing strategy and process technology issues from the bottom to the top of the firm's priority list. The issues surrounding manufacturing technologies and their implementations have assumed greater importance in the manufacturing strategy debate. Practitioners and researchers have developed strong interest in how AMT can be used as a competitive tool in the global economy. A growing number of organizations are now adopting AMT to cope with recent phenomena in today's competitive environment such as fragmented mass markets, shorter product life cycle and increased demand for customization. Although AMT can help manufacturers compete under these challenging circumstances, they often serve as a double-edged sword, imposing organizational challenges while providing distinct competitive advantage when successfully implemented.

International business strategies frequently demand the transfer of manufacturing processes. Manufacturing process is defined as any repetitive system for producing a product, including the people, equipment, material inputs, procedures and software in that system. An issue of importance in this strategic decision is whether the process should be transferred without modification or adopted in some way for transfer.

Owing to the intense global competition in manufacturing, manufacturers need to increase their level of competitiveness in the global market. Some manufacturing companies, therefore, are forced to undergo a period of transformation in order to compete more effectively. Under these circumstances, AMT is considered as a means of improving competitiveness.

The term AMT refers to computer-aided technologies in design, manufacturing, transportation and testing, etc. In general, AMT can be categorized into two principle ways:

The classical continuum of basic manufacturing processes which extends from make-to-order manufacturing to continuous manufacturing ; and the level of integration of the overall manufacturing system.

AMT provides an organization with an opportunity to successfully combat market place dynamics and create for itself a competitive advantage. Manufacturers and academics believe that AMTs can reduce operating cots, provide high levels of output by removing inconsistent human input, improve manufacturing flexibility and lead time to market.

The literature on Advanced Manufacturing Technologies can be divided in to different fields but all fields are interrelated and those fields are as follows: 
(i) Adoption of Advanced manufacturing technologies

(ii) Investment of AMT

(iii) Selecting and Assessment of AMT

(iv) Planning and Implementation of AMTs

(v) Historical development of AMT

(vi) Definitions and Group of AMTs

(vii) Benefits and Disadvantages of AMT

\section{Definitions of AMT}

Numerous definitions of AMT exist. For example, Baldwin (1995) defines AMT as 'a group of integrated hardware-based and software-based technologies, which if properly implemented, monitored, and evaluated, will lead to improving the efficiency and effectiveness of the firm in manufacturing a product or providing a service.' This work, however, provides a more global definition that combines the work of Zhao, and Zammuto and O'Connor (1995). AMT, defined broadly, is a total socio-technical system where the adopted methodology defines the incorporated level of technology. AMT employs a family of manufacturing (CAM), flexible manufacturing systems (FMS), manufacturing resource planning (MRP II), automated material handling systems, robotics, computer-numerically controlled (CNC) machines, computer-integrated manufacturing (CIM) systems, optimized production technology (OPT), and just-in-time (JIT). Although AMT places great emphasis on the use of technological innovation, management's role is significant since AMT systems require continual review and readjustment.

Advanced Manufacturing technology (AMT) represents a wide variety of mainly computer-based systems, which provide adopting firms with the potential to improve manufacturing operations greatly. It is generally expected that the resultant improvement in operational performance will enhance the firm's ability to reap the underlying marketing, strategic and business benefits for which the systems were adopted. Another definition is AMT refers to a family of technologies that include computer-aided design (CAD) and engineering systems, materials resource planning systems, automated materials handling systems, robotics, computer controlled machines, flexible manufacturing systems, electronic data interchange and computer-integrated manufacturing systems.

AMT represents a wide variety of modern computer-based systems devoted to the improvement of manufacturing operations and thereby enhancement of firm competitiveness.

Global competition continues to drive the adoption of advanced manufacturing technology (AMT) to date, the literature AMT on the introduction of AMT new technology is based primarily on case studies and expert opinions.

AMT has been described as programmable machinery or a system of programmed machines that can produce a variety of products or parts with virtually no time lost for changes. The process of introducing AMT is generally evolutionary but in some settings the pace is quickening. As innovations spill over into practical application there is a simultaneous change in the mix and range of elements generally labeled as AMT. The machines, computer control and linkages, as well as the human operator involvement, appear to be on a windy route from islands of technology towards some far wider degree of computer integration, referred to as computer integrated manufacturing (CIM). 
AMT represents a wide variety of modern computer-based or numerical controlbased systems devoted to the improvement of manufacturing operations. AMT is broadly defined as 'an automated production system of people, machines and tools for the planning and control of the production process, including the procurement of raw materials, parts and components and the shipment and service of finished products. The properties of AMT overcome the limitations of conventional technology in enabling small firms to develop economies of scope based on low volume and low cost production. Specifically, AMT facilitates customization and reduces lead times through the productions of variety, frequent design changeovers, and rapid processing of design, assembly, materials handling and market information.

In general, AMT typically involves (a) a computer-aided design system (CAD) that develops designs, displays them and stores them for future reference: (b) a computer-aided manufacturing system (CAM) that translates CAD information for production and further controls machine tools, material flow, and testing; (c) an automotive storage and retrieval system for delivery or pack up of parts between machines and storage: and (d) a supervisory computer that integrates all of the above (CIM).

AMTs refer to a family of technologies that include computer-aided design (CAD) and engineering systems, materials resource planning systems, automated materials handling systems, robotics, computer-controlled machines, flexible manufacturing systems, electronic data interchange and computer-integrated manufacturing systems.

\subsection{Group of AMT}

Advanced manufacturing Technologies involve the application of computers to various facets of the production process. The 22 manufacturing technologies are grouped into six functional categories, each capturing a different aspect of the process-fabrication and assembly, automated materials handling systems, design and engineering, inspection and communications, manufacturing information systems, or integration and control. Table 1 presents the technologies and groups used in Canadian Manufacturing Survey (1995).

There are 26 AMTs listed in Baldwin's (1995) survey. The list is obtained from Statistics Canada in 1995. The 26 technologies belong to six functional technology groups-design and engineering; processing, fabrication, and assembly, automated material handling, inspection, network communications, and integration and control.

Advanced manufacturing technologies (AMTs) involve new manufacturing techniques and machines combined with the application of information technology, microelectronics and new organizational practices within the manufacturing process. These hardware technologies have found wide acceptance in discrete manufacturing and in resource and processing sectors. Computer numeric controls have been applied to systems for machining, forming, cutting and molding. The accuracy, speed and control of robots have improved significantly and, as a result, they are used extensively in welding, painting, material handling and an enormous number of unique assembly applications. Vision systems provide, in real time, monitoring for precision machining and highspeed printing and remote handling of mining equipment used thousands of 
Metrecs underground. Computer-aided design (CAD) and rapid prototyping have substantially shortened the development time for new products. Computerintegrated manufacturing (CIM) is applied in machine shops for tool building, the production of engines and body assemblies for passenger cars, the manufacture of airplane landing gear and the production of hypodermic needles for the medical devices sector.

Complementary to the hardware technologies of AMTs is a wide range of 'soft' manufacturing process technologies. Just-in-time (JIT) manufacturing, total quality management (TQM) and supply chain management are but a few of the many 'soft' AMTs adopted by manufacturers and processors globally.

The nature of competition in manufacturing has changed. High-quality and highly customized goods are demanded. There is a premium for being the first to market with a product. This has created a demand for 'hard' and 'soft' technologies that help shorten design and production cycles. Freer trade has increased the breadth of geographical competition, making it easy for foreign manufacturers to enter the Sri Lankan market and for Sri Lankan firms to enter foreign markets. The source of this competition varies, some of it from low-wage areas and some of it from very technologically sophisticated countries.

Manufacturing practices and processes have come under increased pressure from global competition. Demands for improved customer service, breadth of product line, improved quality, quick response and a much shortened time-tomarket for new product introduction cannot be ignored by firms. In the face of these intense pressures, Sri Lankan and other manufacturers around the world are moving away from mass production manufacturing processes. They are turning to greater flexibility and speed in manufacturing practices. These practices have become the foundation for 'Best in Class' manufacturers and processors.

Manufacturing has been influenced by trade liberalization, global competition, market fragmentation, technological innovation and the demands of more sophisticated consumers. In response to these pressures, manufacturers are incorporating more flexibility and technology in their production practices. These features have become a trademark of world-class corporations. AMTs are a key enabler for firms attempting to meet world-class performance targets. 
Table 1. Type of Advanced Manufacturing Technologies

\begin{tabular}{|c|c|}
\hline Functional Group & Technology \\
\hline $\begin{array}{l}\text { Processing, Fabrication } \\
\text { and Assembly }\end{array}$ & $\begin{array}{l}\text { Flexible manufacturing cells or systems } \\
\text { (FMC/FMS) } \\
\text { Programmable logic control machines or processes } \\
\text { (CNC and NC) } \\
\text { Lasers used in materials processing } \\
\text { Robots with sensing capabilities } \\
\text { Robots without sensing capabilities } \\
\text { Rapid Prototyping systems } \\
\text { High speed machining } \\
\text { Near net shape technologies }\end{array}$ \\
\hline $\begin{array}{l}\text { Automated Material } \\
\text { Handling }\end{array}$ & $\begin{array}{l}\text { Part identification for manufacturing automation } \\
\text { (bar coding) } \\
\text { Automated storage and Retrieval system (AS/RS) } \\
\text { Automated Guided Vehicle Systems (AGVS) }\end{array}$ \\
\hline Design and Engineering & $\begin{array}{l}\text { Computer-aided design and engineering } \\
\text { (CAD/CAE) } \\
\text { Computer-Aided Design/Manufacturing CAD/CAM } \\
\text { Modeling or simulation Technologies } \\
\text { Electronic exchange of CAD files } \\
\text { Digital representation of CAD output }\end{array}$ \\
\hline $\begin{array}{l}\text { Inspection and } \\
\text { Communications }\end{array}$ & $\begin{array}{l}\text { Automated Vision-based systems used for } \\
\text { inspection/testing of inputs/or final products } \\
\text { Other automated sensor-based systems used for } \\
\text { inspection/testing of inputs }\end{array}$ \\
\hline $\begin{array}{l}\text { Manufacturing } \\
\text { Information Systems }\end{array}$ & $\begin{array}{l}\text { Manufacturing Resource Planning (MRP) } \\
\text { Manufacturing Resource Planning (MRP11) }\end{array}$ \\
\hline Integration and Control & $\begin{array}{l}\text { Supervisory Control \& Data Acquisition (SCADA) } \\
\text { Artificial Intelligence/Expert Systems (AI) } \\
\text { Computer Integrated Manufacturing (CIM) }\end{array}$ \\
\hline
\end{tabular}


The functional groups and their constituent technologies, along with a brief description of each, are provided in Table 1. AMT is a generic term for a group of manufacturing technologies, which combine both scope and scale capabilities in a manufacturing environment. Manufacturing strategy has become more sophisticated. As a result, AMT can play a crucial role in making it possible for firms to compete on 'traditionally' contradictory competitive priorities simultaneously.

Baldwin (1995) suggests two subgroups of technologies within AMT: the traditional hardware technology consisting of systems, devices and stations (SDS): and a second group of technologies, often in software form, which perform integrative and managerial functions-integrative and managerial systems (IMS).

Typical examples of systems, devices, and stations (SDS) include automated identification station, automated inspection stations, automated material handling devices, computer aided design workstations, computerized numerical control machine tools, numerical control machine tools, programmable production controllers, robots, shop-floor control systems.

Examples of integrated and managerial systems (IMS) include computer aided manufacturing, computer-aided engineering, statistical process control, production planning/inventory management software, engineering data management, computer aided process planning, local area networks, group technology.

Both SDS and IMS technologies can be used individually or in combination with other technologies to achieve desired economies of scale and scope. When taken together SDC and IMS constitute AMT.

AMT represents a wide variety of mainly computer-based systems that provide adopting firms with the potential to improve manufacturing operations greatly. It is generally expected that the resultant improvement in operational performance will enhance the firm's ability to reap the underlying marketing, strategic and business benefits for which the systems were adopted. Some of the benefits attributed to these technologies are improving market share, gaining earlier entrance to market share, responding more quickly to changing customer needs and the quality to offer products with improved quality and reliability.

These technologies have been classified as stand-alone systems, intermediate systems and integrated systems. Technologies such as computer aided design (CAD) and computer numerical control machines (CNC) are typically categorized as standalone systems. Automated material handling systems (AMHS) and automated inspection and testing systems (AITS) are classified as intermediated systems. Integrated technologies can be categorized as either integrated process technologies (e.g. computer manufacturing systems (CIM) and flexible manufacturing systems (FMS) or integrated information/logistic technologies (e.g. just-in-time production (JIT) and manufacturing resources planning (MRPII). The general trend in the AMT research literature has been to examine technology adoption and any resultant change in firm performance on the basis of the implementation of individual technologies or in terms of implementation of specific technology classifications such as those presented above. 
AMTs refer to a family of technologies that include computer-aided design (CAD) and engineering systems, materials resource planning systems, automated materials handling systems, robotics, computer controlled machines, flexible manufacturing systems, electronic data interchange and computer-integrated manufacturing systems (Zammuto and O'Connor, 1992). Numerous studies have emphasized the potential strategic benefits of flexibility, responsiveness, improved quality and improved productivity through purposeful investment in AMTs. Such benefits are increasingly important in the current global manufacturing environment, which has been described as hyper competitive, high-velocity and characterized by fragmenting markets, shorter product life cycles, and increasing consumer demand for customization (Zammuto and O'Connor, 1992). Thus, AMTs have, and will continue to have, a key strategic role in improving competitiveness by utilizing the manufacturing function more effectively in overall business strategy.

AMT includes a group of integrated hardware-based and software-based technologies which, when properly implemented, monitored and evaluated, can improve the operating efficiency and effectiveness of the adopting firms. They encompass a broad range of computer-based technological innovations, which include numerical control (NC) machine tools, cellular manufacturing, machining (CAD/CAM) systems, and automated storage and retrieval systems (AS/RS). These islands of automation are integrated manufacturing (CIM). AMT has the potential to improve operating performance dramatically and create vital business opportunities for companies, which are capable of successfully implementing and managing them.

AMT can also provide distinctive competitive advantages in cost and process leadership. Events of the last decade, such as the US productivity problems, Japanese manufacturing success stories and the competitive global economy, have moved manufacturing strategy and process technology issues from the bottom to the top of the firm's priority list.

The AMTs are broadly classified into seven sub-groups. The classification scheme adopted here is similar to the US Department of Commerce Survey of Manufacturing Technology. The findings of some researchers show that the technologies are cross categorized as stand-alone systems and integrated systems. This classification scheme links technologies that have similar benefits and costs. The 14 technologies are classified into three main groups, and seven sub-groups are further divided as shown in Table 2.

Table 2. Classification of AMT

Stand-alone systems

1. Design and engineering technologies Computer-aided design (CAD)

Computer-aided process planning (CAPP)

2. Fabricating/machine and assembly technologies $\mathrm{NC/CNC}$ or DNC machines

Materials working laser (MWL)

Pick-and -place robots

Other robots

Intermediate systems 
3. Automated material handling technologies

Automatic storage and retrieval systems (AS/RS)

Automated material handling systems (AMHS)

4. Automated inspection and testing systems

Automated Inspection and testing equipment (AITE)

Integrated systems

5. Flexible manufacturing technologies

Flexible manufacturing cells/systems (FMC/FMS)

6. Computer-integrated manufacturing systems

Computer-integrated manufacturing (CIM)

7. Logistic related systems

Just-in-time (JIT)

Material requirements planning

Manufacturing resources planning (MRPII)

Companies must ascertain which technologies can fulfill their objectives and identify the selected technologies belonging to a system, since it will affect the following justification methods chosen. For stand-alone systems where the purpose is the straightforward replacement of old equipment, even if some economic benefits not usually considered are obtained, the standard economic justification approaches can be used.

There is another grouping method based on the amount or type of investment. Nature of the AMT investment can be divided into three-section computer hardware, computer software and plant and equipment.

(1) AMT related hard ware:

LAN (local area networks)

Micros (PC Computers)

Graphics hardware:

Mainframe

Online process instrumentation

Shop floor data capture

WAN (wide area networks)

(2) AMT related Software:

$\mathrm{CAD} / \mathrm{CAM}$

Data base management systems

MRPII (Manufacturing Resource planning I and II)

(3) QC software

MRP

Expert systems

OPT

MAP

(4) AMT related plant and equipment:

CNC M/Cs

Automatic testing equipment

Computer-controlled testing equipment

Flexible manufacturing cells

Automatic assembly

Flexible assembly systems

Robots

Laser cutting

Automated warehousing/order picking

AGVs

Laser measuring 
Generic Advanced Manufacturing Technologies and Practices is another AMT grouping. Generic AMT represent the different generations and different capabilities that crosscut most industries.

(1) Multi-axes machining center

(2) High speed machining center

(3) Cellular manufacturing or group layout

(4) Computerized production planning system

(5) Product modeling and simulation

(6) Electronic exchange of product design and process data

(7) Automated parts identification devices

(8) Rapid set tooling and fixturing

(9) Rapid prototyping

(10) Computerized process planning system

(11) Product data management system

(12) Process simulation

(13) Knowledge-based systems

(14) On-line intelligent process control

Advanced manufacturing technologies refer to a family of technologies used in all facets of manufacture including design, control, fabrication and assembly. AMTs have taken on many forms of acronyms, including computer-aided design (CAD), computer aided engineering (CAE), manufacturing resource planning (MRPII), automated materials handling system, electronic data interchange (EDI), computer integrated manufacturing (CIM) systems and flexible manufacturing cell (FMC).

\subsection{Empirical Evidence of Productivity increases of the firm}

Sufficient evidence exists that computer aided technologies can increase productivity as well as quality and production flexibility. In a study of 14 organizations that have deployed computer-aided manufacturing technologies, Voss found that 12 had experienced increases in productivity. Increased product quality, reduced lead-times, and greater flexibility occurred in 8 of them. On the other hand, a pioneer study by Jaikumar (1986) found that deployment of computer-aided technologies in some firms only boosted machine up time and productivity or lead-times. Jaikumar concluded that these organizations did not realize increase in quality and flexibility because they superimposed the new technologies on existing structured organizations. Gaining the inherent flexibility and quality advantages of computer-aided technologies requires a more integrated and flexible work organization with decentralized control structures.

Computer-aided technologies are similar to earlier conventional nonprogrammable fixed-cycle technologies because of their ability to increase machine up time and produce high volume products. Scale economies needed to be competitive in mass markets can thus be reaped with computer-aided technologies. Nonetheless, these new technologies differ from conventional machines because they have the capacity to produce a wide array of low volume, high quality, customized parts or products needed for a highly segregated market (Zammuto and O'Connor, 1992). 
The issues surrounding manufacturing technologies and their implementations have assumed greater importance in the manufacturing strategy debate. Practitioners and researchers have developed strong interest in how AMT can be used as a competitive tool in global economy. A growing number of organizations are now adopting AMT to cope with recent phenomena in today's competitive environment such as fragmented mass markets, shorter product life cycle and increased demand for customization. AMT can help serve as a double-edged sword, imposing organizational challenges while providing distinct competitive advantage when successfully implemented.

\subsection{History of AMT}

Historically, manufacturing organizations made improvements in their productions processes primarily through investments in physical capital. Advices in mechanization, for example, enabled manufacturing firms to enhance efficiency in production while actually lowering the required skills and capabilities of employees. As a result, many firms actually took the tactic of deskilling their workforces to reduce labor expenses, thereby diminishing the necessary level of investments in human capital with the hope of increasing profits.

In contrast to this perspective, advocates of the cotemporary manufacturing paradigm argue for a dramatically different orientation toward employees. These post-industrial theorists propose that compared to the deskilling tactics of traditional manufacturing, more advanced systems require a set of complementary practices for upskilling the workforce. Indeed, some studies have suggested that modern manufacturing systems demand more enhanced technical, conceptual, analytic and problem solving skills than typically were required in traditional manufacturing environments.

In the manufacturing sector, the new technological advances have revolved around machine tools and equipment. Advances in automation of machine tools began about 30 years ago with the first generation of programmable machine tools-the numerical controlled machine tools (NC). The NC did not become widely used until the 1970s. The second generation, computerized numerical control machine (CNC), was introduced in the late 1970s. These new machine tools have the capacity to produce the high volume standardized parts and products necessary for competitive success in undifferentiated markets.

The first AMT technologies were introduced in the 1950s, but it was not until the 1970s that the adoption of AMTs took off and the 1980s that their use became widespread. Today, nearly all currently produced manufacturing equipment incorporates some electronics element and thus fits the definitions for AMTs.

There are three types of manufacturing systems: crafts shops; dedicated manufacturing systems (DMS); and advanced manufacturing technology -based systems (AMT). Their research is based on Teece conceptualization of longlinked versus intensive technologies. Using their classification scheme, DMS are considered long-linked industrial systems employing hard automation whereas AMT are post-industrial enterprises employing flexible resources.

There are many distinctions between craft shops and DMS. While craft shops employ skilled artisans who use various hand tools, DMS deploy special-purpose machinery operated by unskilled manual laborers. In a craft shop, workers are organized into task-oriented work groups. Work is functionally specialized and 
used usually a single task is assigned to a worker in a DMS. In a craft shop, performance measures are based on customs and other craftsmen evaluate the work. DMS are controlled through a hierarchical structure. In addition to the above characteristics, DMS are product-oriented, concerned with efficiency and productivity. An information system controls task execution and co-ordinates sequential activities within a DMS.

\subsection{Adoption of AMT}

The study of the adoption and dissemination of technologies is one of the key components of innovation and technological development. Indeed, it is through the adoption of newer, more advanced technologies that industries can increase their production capabilities, improve their productivity, and expand their lines of new products and services. Adoption of new technologies is a key element to a firm's success. Therefore, this report outlines the extent to which establishments in the Canadian manufacturing sector use advanced technologies. It investigates the extent to which advanced technology is used - both at the individual technology level and at the functional technology group level, where functional group refers to collections of technologies that serve a common purpose. Not all firms adopt advanced technologies because of the costs associated with their adoption. Adoption occurs when the benefits from adopting the new technology outweigh the costs.

Michael Proter (1986) argues that there are two roads to competitive advantage: lower cost or product differentiation. Developing countries are able to again a foothold in international markets for their industries by translating their relatively cheap labor costs into lower-cost goods. For industrialized countries such as the US, where the cost of labor is relatively high, the introduction of such cost competition has undercut many traditional industries, and forced many firms to slash costs in order to remain competitive. In the long run, such strategies cannot pay off for industrialized countries. The competitive advantage of low cost production will always lie with less developed countries.

According to Porter (1986), the road to competitive advantage for industrialized countries that wishes to keep wages relatively high must be product differentiation. Firms must become able to produce goods that cannot easily be transferred to lower cost locations, allowing them to maintain reasonable operating margins while paying higher wages.

Global competition continues to drive the adoption of AMT. To date, the literature AMT on the introduction of AMT new technology is based primarily on case studies and expert opinions.

Global and domestic firms have different objectives for adopting AMT as a means to effectively compete in their respective markets. Whatever the objectives may be, the adoption of any new technology involves uncertainty about achieving the objectives.

In addition to the inherent human resistance to change and innovation, at least two other types of uncertainty are present when adopting manufacturing innovations: technological uncertainty (whether the adoption of the technology will be profitable): and strategic uncertainty (how the decisions of competing firms will be adversely impact a decision to adopt a new technology). Generally, the 
effects of technological uncertainty can be reduced by research and testing. In contrast, strategic uncertainty is more difficult and problematic to evaluate, frequently relying on speculative efforts to anticipate the decisions of rival firms. Adopting AMT involves both types of uncertainty.

Baldwin (1995) suggests that firms, which export a large portion of their production, adopt a greater variety of AMT than domestic competitors. He cites the reorientation to exporting by the Japanese as their motivation to adopt AMT. If this is the case, US exporting firms would be expected to adopt a greater variety of AMT than non-exporting firms.

The adoption of AMT involves major investment and a high degree of uncertainty and, hence, warrants considerable attention within manufacturing firms at the strategic level. As a result, issues involving selection and justification procedures assume greater importance. Baldwin further states that companies can attain significant competitive advantages through AMT such as flexible manufacturing systems (FMSs), computer-aided design and robotic systems. He also observes that many companies are reluctant to install these technologies because:

(1) Those which have frequently do not reap the advantages these technologies can offer.

(2) There are difficulties in implementing the expensive, complex systems.

(3) There are insufficient internal skills.

(4) There is a multiplicity of implementation paths.

(5) AMT involves incremental skill building

(6) AMT requires different support infrastructure

Implementing AMT is one of the lengthiest, expensive and complex tasks a firm can undertake.

An issue of importance in this strategic decision is whether the process should be transferred without modification or adapted in some way for transfer, cloning a manufacturing process can maintain commonality throughout a global network of operations, and avoid re-engineering costs. Cloning, however, requires 'robustness' to the recipient's local conditions and may not allow the exploitation of benefits from local factors of production. The alternative is to adapt some aspect or aspects of the manufacturing process, through adoption; the transferor (the home) can take advantage of local characteristics and can facilitate the transfer process. Manufacturing process which receives significant inputs from the local economy, such as skilled labor, repairmen, reliable power, spare parts, industrial materials processed according to exacting specifications and so on, are less appropriate to the less-developed areas than those which do not have such requirements. Vernon concluded that firms would either vertically integrate to overcome such supply problems, or choose products which were more transferable, such as those which did not require the local conditions mentioned above. Taking a largely economic perspective, he identified the variables affecting technology choice for transfer as: market size and growth, labor and capital costs, range of technology available and prospect of technology obsolescence. In these examples, the author has listed both host-dependent and host-independent issues. To attempt a comprehensive assessment of the factors coming to bear during the transfer it is necessary to differentiate between those characteristics of the process that pertain to fit with host conditions (such as labor costs and market) and those that affect the activity of transferring the process (such as dependence on difficult-to-transfer knowledge). 
Literature on 'technology appropriateness typically suggests factors influencing adaptation to improve fit with host characteristics and socio-economic objectives. Pakes (1984), for example, focuses on labor substitution, identifying appropriate technology as that which maximizes output and employment simultaneously. This approach to appropriateness is too narrow to be of much value to transfer practitioners assessing a manufacturing process or choosing a location. A wide view of appropriateness should draw in all the factors that have some impact on the operation of a manufacturing process in its new location.

Implicitly so far, adoption and adaptation of manufacturing philosophies by less developed countries (LDCs) provides useful material for the search for factors adaptation. The simplicity of Japanese techniques and their low capital investment requirement makes them ideal for LDCs, requiring only training. However, they do mention caveats, for example: workers in LDCs often lack inherent housekeeping tendencies, capability in tool making and quality measurement, and individuals for troubleshooting. More adaptation influencing factors are suggested by authors in LDCs, namely, employee and supplier participation (cultural and infrastructure), educational level, labor costs, unionization, and firms' size.

Factual evidence of the factors affecting manufacturing process adaptation is uncommon, but a number of empirical studies have identified a lack of host managerial know-how, lack of infrastructure, poor IPR protection, governmental requirements and commercial habits as barriers to transfer. Different manufacturing processes will be affected by these factors to a greater or lesser extent. The sensitivity of a process to any of these factors gives an indication of its robustness. If a process was not, for example, climate specific, then it could be considered robust to climate. In this case it would be appropriate, regardless of differences between the home and host climates. The more general case would be where although the process was affected by climate, the home and host climates were sufficiently similar so that the manufacturing process was appropriate for that host.

Adoption of new technologies is a key element to a firm's success. Therefore, most of the researchers outline the extent to which establishments in the Canadian manufacturing sector use advanced technologies. It investigates the extent to which advanced technology is being used-both at the individual technology level and at the functional technology group level, where functional group refers to collections of technologies that serve a common purpose. Not all firms adopt AMT because of the costs associated with their adoption. Adoption occurs when the benefits from adopting the new technology outweighs the costs. Adoption rates, alone, are insufficient for attempting to understand the complex nature of technological change. Thus, some surveys investigate the benefits and effects that manufacturing establishments receive as the results of adopting AMT.

Moreover, some manufacturers hold the view that the adoption of AMT involves a high level of investment, and its payback period is usually longer than that traditionally required by business enterprises.

The top five obstacles to more rapid adoption of AMT, as stated by these executives, are: 
(1). Lack of necessary funding

(2). Lack of in-house technical expertise

(3). Failure of top management to grasp the benefits of AMT

(4). Inadequate planning or lack of vision

(5). Inadequate cost-justification methods

\subsection{Benefits of Advanced Manufacturing Technology}

The literature identifies a variety of technical and strategic factors that include AMT adoption: reduced product development time, labor costs savings, material costs savings, a need to remain competitive, tax incentives, financing availability, a need for product change flexibility, environmental, safety or health concerns, increased profitability or plant performance and customer requirements. These factors have a broad, strategic impact on the firm and affect virtually every major element of a firm's operating environment.

AMT represents a wide variety of modern computer-based systems devoted to the improvement of manufacturing operations and thereby enhancement of the firm competitiveness. AMT, in its varying forms, has been credited with the potential to bestow, among other things, earlier entrance to market, faster responses to changing customer needs, and higher quality products with improved consistency and reliability, However, results of several empirical studies indicate that, while most firms achieve some benefits, many of them are not fully exploiting their AMTs touted capabilities.

Since the technical capabilities of AMT are well proven, failure to achieve the potential benefits has been attributed to infrastructure problems such as inadequate organizational planning and preparation for the adoption of the AMT or defines a life-cycle implementation process which consists of the following three phases: pre-installation (planning and justification), installation and commissioning (monitoring and evaluation). Implementation is typically viewed as a combination of the actions in the installation and commissioning and postcommissioning phases.

\subsection{Disadvantages of AMT}

Companies have identified some of the issues and problems arising from implementing an AMT project and discuss the following issues, namely scope of AMT projects, simulation modeling, cell design, cell operational logistics, and labor issues in AMT.

Traditionally there has been little awareness of the need to link technology issues with human resource management issues. Technologies have been deployed to improve firm performance independent of programs and practices that involve workers in decision-making. Firms implement new technologies to improve their competitiveness. Reductions in labor costs are made possible by new automated machines and equipment which take over decisions about production and perform at accelerated rates operations formerly performed by humans. Faster performing technologies permit increased production using the same fewer, or less skilled employees.

The impediments that were investigated by Baldwin can be divided into five groups. The first includes a set of general cost-related problems associated with AMT adoption, including the cost of capital, the cost of technology acquisition, 
the cost of related equipment acquisition, the cost of related software development, and increased maintenance expenses.

Four other areas were also identified-impediments that arise from government policy (Institutional-related problems), from labor market imperfections, from internal organization problems and from imperfections in the market for information. Each of these also increases the costs of adopting AMT-but the causes are somewhat more narrowly focused than the general cost-related items that are included in the first category.

Labor-related problems include difficulties that arise because new technologies and innovation generally need higher skill levels. In the face of these needs, a firm may encounter impediments to adoption if there is a shortage of skills available on the market, or if it faces training difficulties in overcoming deficiencies, or if its labor contracts act to constrain its ability to substitute labor across tasks.

Organizational problems are those associated with difficulties in implementing the types of internal change in a firm that are required for the adoption of AMTs. The first of these is the difficulty in introducing important changes to the organization. For example, the introduction of computer-aided design may require new structure that link engineering development with the production department so that the advantages of concurrent engineering practices can be fully exploited. Other organizational problems stem from a poor attitude of senior management towards new technologies, or worker resistance.

Institution-related problems are those associated with tax regimes (both the R\&D tax credit and capital cost allowances) and with government regulations and standards. Information-related problems arise if markets for knowledge are imperfect.

They include lack of scientific and technical information, technological services, and technical supports from vendors. Table 3 reports the percentage of plant managers who reported that these problems impeded the adoption of AMT according to the Baldwin (1995) survey.

Table 3 - Problems Impeded the Adoption of AMT

\begin{tabular}{|l|c|}
\hline \multicolumn{1}{|c|}{ Types of Impediment } & Percentage \\
\hline Cost-related & 79.1 \\
\hline Institution-related & 15.5 \\
\hline Labor-related & 37.2 \\
\hline Organization-related & 34.1 \\
\hline Information-related & 24.9 \\
\hline
\end{tabular}

\subsection{Role of AMT in Sri Lanka}

Almost all developing countries that were British colonies for a considerable length of time inherited the British Education system. During the early years of the colonial period, British investors set up most of the sizable businesses in these countries. The managerial personnel, including Production Managers, for these enterprise were generally brought from the UK. Singapore and Sri Lanka were British colonies for nearly one hundred and fifty years. Both of these 
countries inherited their education system and practice almost entirely from the British systems.

During the colonial period, business activity in Sri Lanka was directed towards the plantation sector introduced to the economy by the British. In order to facilitate the investment of British capital, plantation joint stock companies were introduced in the middle of the nineteenth century. The Sri Lankan government has found that companies gain and sustain international competitive advantage through improvement, innovation and upgrading. Research in the early 1990s showed that many Sri Lankan companies were failing to compete effectively. Productivity in Sri Lankan firms had been relatively low by other countries standards.

Various attributes are addressed and used by researchers for procedures involving adoption, classification, selection, and justification of AMT. In this review, a comprehensive list of studies have been identified and classified under many categories. The literature also observes common difficulties in implementing AMT such as lack of technical skills, managerial problems, lack of confidence to implement automated systems, lack of clear-cut policy direction towards automation, resistance to adapt automation and systematic evaluation methods. Economic issues alone are inadequate to justify new manufacturing systems because traditional evaluation methods are inadequate for the purpose. Non economic benefits could not be included in the justification procedure, which offer a large number of intangible benefits. The problem lies not in the level of technology, but rather with its implementation. It is important to note that, instead of rushing to invest in AMT, a manufacturing company must reassess its direction, strengths and weaknesses, and develop a strategy for successful implementation accordingly. The entire literature review and classification scheme suggested have brought several elements to the fore. These can be summarized as follows:

- $\quad$ AMT adoption factors and adaptation and implementation problem by focusing on issues of specific interest.

- AMT involves a set of quantifiable and non-quantifiable attributes.

- $\quad$ AMT definition has changed from time to time. It starts from broad definition and ends up with a much computer related field.

- $\quad$ AMT includes many issues, especially human issue and mechanical issues.

- Advantages and disadvantages related to AMT studies are common in the literature.

\section{Conclusion}

The properties inherent in Advanced Manufacturing Technology (AMT) create new opportunities for firms, and in particular small firms in the local context. The capability of this technology to modify production specifications quickly and accurately means that firms can customize their products and attain economics of scope based on low volume and low cost production. While traditionally technology has been perceived merely as a tool in implementing business strategy, AMT has the potential to directly affect the firm's strategy choices. To date, however, AMT literature suggests that adoption of AMT offers firms the potential to pursue new innovative strategies. 


\section{References}

Armstrong, J. A. 1993. University-Research--New Goals, New Practices. Issues in Science and Technology. Vol.9 (2) : 50-53.

Attaran, M. 1986. Flexible manufacturing systems: Implementing an automated factory. Information systems management. Vol. 9. No. 2 : 44-7.

Association of American Universities. 1986. Trends in Technology Transfer at Universities: Report of the Clearinghouse on University-Industry Relations, (Washington, DC).

Atkinson, R 1991. Innovation Policy Making in a Federalist System: Lessons from the States for US Federal Innovation Policy Making. Research Policy Vol. 20(6) :559.

Audretsch, D.B. and M. Vivarelli. 1996. Firms size and R\&D spillovers: Evidence from Italy. Small Business Economics, Vol. 8(3) : 249-258.

Backer, T. E 1995. Assessing and Enhancing Readiness for Change Implications for Technology Transfer. NIDA Research Monograph, Vol. (1) : 21.

Backer, T. E. \& S. L. David 1995. Synthesis of Behavioral Science Learnings About Technology Transfer. NIDA Research Monongraph, : 262.

Badiru, A.B., Foote, B.L and Chetupuzha, J., 1991: A multiattribute spreadsheet model for manaufacturing technology justfication. Computer and Industrial Engineering, Vol.21 No,1-4 : 29-33.

Bagur, J., and Guissinger, A. 1987. Technology transfer legislation: An overview. Vol.12:51-63.

Baldwin, J., and D. Sabourin .1999. Innovative Activity in Canadian Food

Processing

Establishments: The Importance of Engineering Practices, Analytical Studies

Research Paper, Ottawa: Statistics Canada.

Baldwin, J., D. Sabourin and M. Rafiquzzaman. 1996. Benefits and Problems

Associated with Technology Adoption in Canadian Manufacturing, Catalogue 88-

514, Ottawa: Statistics Canada.

Baldwin, J., D. Sabourin and D. West .1999. Advanced Technology in the

Canadian

Food Processing Industry, Catalogue 88-518, Ottawa: Statistics Canada.

Balachandra, R. 1996. International technology transfer in small business: A new paradigm. International Journal of Technology Management, Vol.12 (5-6) : 625638.

Conn-Farkas, I.1988. Human aspects of information management for technology transfer. Information Management Review. Vol.( 4) : 47-56.

Conner, K and Prahalad, C. 1996. A Resource-based Theory of the Firm; Knowledge versus Opportunism. Organization Science, Vol.7 : 477-501.

Conflicts Of Interest In University Technology Transfer. 1991. Chemtech, Vol. 72-3.

Conner, K. R. \& Prahalad C. K. 1996. A Resource-Based Theory of the Firm: Knowledge versus Opportunism. Organization Science, Vol. 7, 1: 477-501.

JAIKUMAR, R. 1986. Post-Industrial Manufacturing, Harvard Business Review, Nov.- Dec., 66-76.

Packes, A and Schankerman, M. 1984. The rate of Obsolescence of patents, research gestation lags, and the private rate of return to research resources in R\&D, Patents and Productivity, 73-88.

Porter, Michael E. 1985. Competitive Advantage: Creating and Sustaining Superior Performance, New York: The Free Press. 
Samli, A. 1985. Technology transfer: the general model, Technology transfer, Quorum Books, Westport, CT: 3-15.

Sanchez, R. \& J. T. Mahoney. 1996. Modularity, Flexibility, and Knowledge Management in Product and Organization Design. Strategic Management Journal, Vol. 17, Special Issue Winter: 63-76.

Sanders, J D. 1994. Transfer or ?. Journal of Technology Transfer, 19(2): 3.

Sanzmenendez, L. 1995. Policy Choices, Institutional Constraints And Policy Learning - The Spanish Science And Technology Policy In The Eighties. International Journal of Technology Management, 10(4-6): 622-641.

Sapienza, A.M. 1989. Technology transfer: An assessment of the major institutional vehicles for diffusion of U.S. biotechnology. Technovation. 9(6).

Scarso E., and E. Bolisani 1996. Technology transfer to supplier-dominated sectors: Lessons from the diffusion of CAD in the fashion industry. International Journal of Technology Management, 12(4): 421-437.

Schmanner, R.W 1985. Making Business location decisions, Prentice-Hall : Englewood Cliffs, NJ.

Statistics Canada. 1988. Survey of Manufacturing Technology 1987. Final report. Ottawa.

Statistics Canada.1991. Survey of Manufacturing Technology 1989, Indicators of Science and Technology, Catalogue 88-002, Vol. 1, No. 4. Ottawa.

Yong, S. and R. Gaertner 1994. Technology Transfer From University To Industry: A Large-Scale Experiment With Technology Development And Commercialization(presented at the Symposium On Technology Transfer And Public Policy). Policy Studies Journal, 22(2): 384-99.

Yoshikawa, A. 1988. Technology transfer and national science policy: biotechnology policy in Japan. International Journal of Technology Management, 3 (6): 735.

Yoshikawa, A. 1990. Japanese Biotechnology - Government, Corporations, and Technology Transfer. Journal of Technology Transfer, 15, (1 \& 2): 53.

Yoxen, E. J. 1984. Scepticism about the Centrality of Technology Transfer. Social Studies of Science,14(2).

Yu H. Y. and K. S. Yeh. 1996. Technology transfer in Taiwan's information industry: The lessons. Research Technology Management, 39(5): 26-30.

Yuan, J. D. 1996. United States technology transfer policy toward China: PostCold War objectives and strategies. International Journal, 51(2): 314-338.

Zander, U. \& Kogut, B. 1995. Knowledge and the Speed of the Transfer and Imitation of Organizational Capabilities: An Empirical Test, Organization Science, 6: 76-92.

Zammuto,R.F and O'Connor, E. 1995. Gaining advanced manufacturing technologies' benefits: the role of organization design culture, Academy of management review, Vol.17 No.4,192:701-28.

Zaheer, S. 1995. Overcoming the liability of foreignness. Academy of Management Journal, 38(2): 341-363. 